Andrei Jean Vasile ${ }^{1}$

Zaharia Marian²

Petroleum-Gas University of Ploiesti,

Faculty of Economic Sciences, Romania

Bogdan Bazgă $\breve{~}^{3}$

National Intelligence Academy „, Mihai Viteazul”,

Bucureşti, Romania
ORIGINAL SCIENTIFIC ARTICLE doi:10.5937/ekonomika1602001J

Received: February 29, 2016

Accepted: April 27, 2016

\title{
ASPECTS REGARDING THE EVOLUTION OF THE CONSUMER PRICE INDICES IN ROMANIA, DURING 1991-2015. IS ROMANIA PRICE SAFETY?
}

\begin{abstract}
Prices are an essential barometer in assessing, both consumer behavior, orienting production towards those categories of products sold in the market but mainly provides information on economic developments in general. Pricing behavior also provides reliable information in the assessment classical report demand vs. offer. Rapid price increases are the results of a complex combination of structural and temporary factors. From this perspective, understanding and explanation as possible of the evolution of prices is a necessary step in adopting the general economic measures and policies to remove some of their volatility. The main aim of this paper is mainly focused on an analysis regarding the evolution of the consumer price indices in Romania, during 1991-2015, trying equally to explain if Romania is price safety.
\end{abstract}

Key words: prices, demand, consumer behavior, ANOVA, econometric modeling.

JEL classification: E20, E30, E31

\section{АСПЕКТИ ВЕЗАНИ ЗА ЕВОЛУЦИЈУ ИНДЕКСА ПОТРОШАЧКИХ ЦЕНА У РУМУНИЈИ, ТОКОМ 1991-2015. ДА ЛИ РУМУНИЈА ИМА БЕЗБЕДНЕ ЦЕНЕ?}

\begin{abstract}
Апстракт
Цене су од суштинског значаја оне су барометар у проиени понашања потрошача, оријентишу производюу према тим категоријама производа који се продају на тржишту, али углавном дају информаџије о економским кретањима у иелини. Цена понашање такође пружа поузане информације у прочени класичног извештаја захтева против понуде. Брзи раст иена су
\end{abstract}

\footnotetext{
${ }^{1}$ andrei_jeanvasile@yahoo.com

${ }^{2}$ zahariamamarian@yahoo.com

${ }^{3}$ bogdan.bazga@gmail.com
} 
резултати сложене комбинације структурних и привремених фактора. Из ове перспективе, разумевање и објашњење је могућа еволуција иена која је неопходан корак у усвајању општих економских мера и политике да се уклоне неке од юихових нестабилности. Главни циль овог рада је углавном фокусиран на анализу која је у вези са еволуцијом индекса потрошачких цена у Румунији, током 1991-2015, покушавајући једнако да објасни да ли у Румунији постоји безбедност ичена.

Кључне речи: иене, потражња, понашања потрочача, АНОВА, економетријска моделирања.

\section{Introduction}

Manifestation of some improper economic states among others the economic crisis, within the evolution of the European economy or the international economic instability are key factors in amplifying the consumer prices volatility in Romania. The price evolution is closely connected to the effects of economic policy measures adapted to the national economy and react to them in a high volatility regime. The lately fluctuations in prices analyzed it suggest that the domestic prices must accept the increasingly volatile consumer prices. Adapting to some speculative price manipulation methods that do not reflect reality but existing demand in the market for certain products requires the existence of a fence of flexibility which is often incompatible with the requirements and defining characteristics of the EU domestic production imported. Numerous studies as (Verhallen and Robben, 1994; Breitung and Candelon, 2006; Assenmacher-Wesche and Gerlach, 2008; Caporale et al., 2002) reflect the connections between the classical factors and influences on the consumer prices.

The economic instability and the price's fluctuation imposed steep prices, despite a recent recovery in the national economy to rethink their position in European economic space. Price developments suggest a degree of uncertainty for the savings. The consumer price volatility indices are determined by a wide range of factors, these include price volatility and food products market impulses and scenarios.

In literature connexion between evolution of the price indexes and different types of determinants is widely analyzed. In this context, (Liping et al., 2014) evaluates how the oil price shocks affect consumer prices through a series of factors on disaggregate the U.S. consumer prices or how the institutions responds to such factors (Kilian and Lewis, 2011). Others authors as(Parguel et al., 2016) analyzes the impact of price display in the luxury sector, or develops investigations regarding the place and promotion policies and displays of more accessible prices as (Truong et al., 2009). As it is argued in literature (Skoufias, (2003); Gros and Steinherr, (2004); Svejnar, (2002); Mieila, (2012); Chivu and Ciutacu, (2014), after the fall of the communism Romania economy transition process towards the market economy and its step by step becoming part of the European and world economy generated evolutions of the inflation rates with significant values and amplitude, especially during the period subsequent to the revolution in 1989. After 2000 these values have been considerably diminished, the trajectories of the monthly average 
inflation rate and monthly average change of prices for food goods, non-food goods and for services tending to become stable. In Romania numerous papers provide examples of using IT in elaborating and testing the econometrics models both in economy (Andrei \& a.1. 2008, Pecican 2007, Oprea \& Zaharia 2011), and in financial market (Săvoiu \& Necşulescu 2009, Trencea \& Mutu 2012, Zaharia and Bălăcescu 2011) domains.

\section{Specific Features of the Period 1991-2001}

Within that decade the monthly average inflation rate has registered considerable high values (over $8.0 \%$ ) in 1991 (10.3\%), 1992 (9.6 \%), 1993 (12.1\%, the highest value for the analyzed period ) and 1997 (8.0\%). The restructuring processes, the governmental and local policies, inappropriately chosen most of the times, and also the inertia characterizing the mentality of an important part of the population represent only a few elements which made possible the monthly average inflation rate maintain its values higher than $2.0 \%$ (Figure 1) for a12 years period (1991-2001).

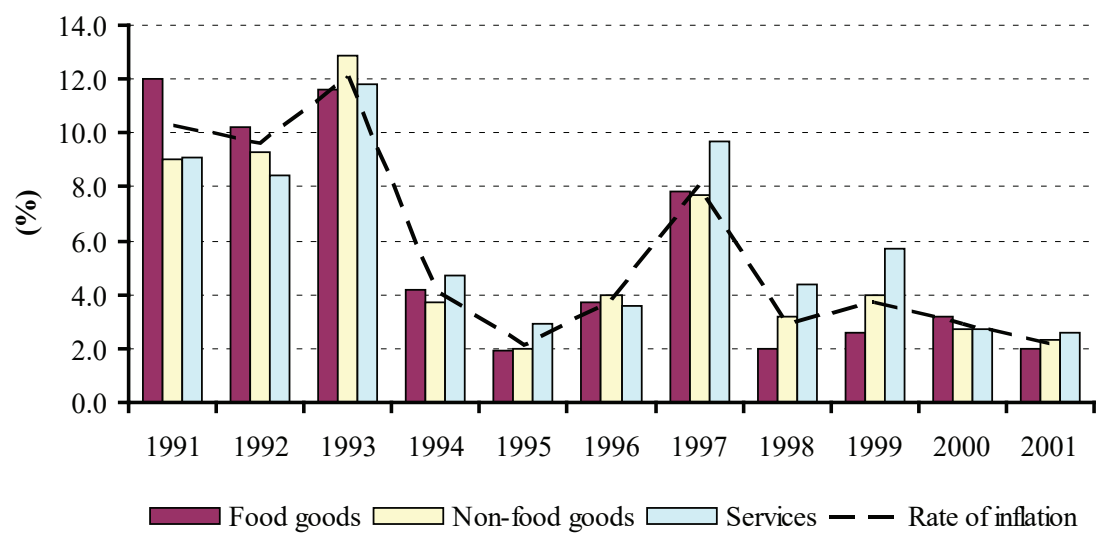

Figure 1. Evolution of monthly average inflation rate and monthly average change of prices for the period 1991-2001. Source: own construction based on Prices Statistical

Bulletin, National Institute of Statistics (NIS 2015), Data series Change of prices monthly average.

If between 1991- 1993 monthly average inflation rate registered high values, during 1994-1996 the values decreased with over 50\% compared to 1993 , being placed between $2 \%$ and $4 \%$. The governmental policies which were applied after the elections in 1996 and the significant fall in value of the national currency compared to EUR consequently determined, in 1997, the increasing of the monthly average inflation rate from $3.8 \%$ (value registered in 1996), to $8.0 \%$ (a rise of 2.1times). Even if the 1998 monthly average inflation rate decreased to $2.9 \%$, in 1999 a new rise, with a value of $3.7 \%$ took place. Taking into account the monthly average inflation rate it can be concluded that the period 1996-2000 emphasized a significant decrease of the population purchase power with consequences on the economic stability and level of living; as a 
result, there have been necessary almost five years in order to recover the level of about $2.0 \%$ monthly average inflation rate de approximately 2.0 necessary

Monthly average change of prices for food goods, non-food goods and services, in 1991, 1992 and 1993 has also registered significant values. Thus, in 1991, the value for food goods was $12.0 \%$ (the highest value within the analyzed period for this category of goods), with 1.7 percentage points over the monthly average inflation rate. However, it should be outlined that, excepting 2000, during the period 1995-2001 the values of monthly average change of prices for food goods were lower than monthly average inflation rate.

On one side, in the case of non-foods, the monthly average change of prices, in six years out of the total of 11 years during the period 1991-2001, the values registered have been under the monthly average inflation rate, the most important difference $(-1.3$ percentage points) being registered in 1991. On the other side, the monthly average change of prices for non-food products in 1993, outrun the monthly average inflation rate by 0.8 percentage points. Monthly average change of prices for services fluctuated around the monthly average inflation rate with values between -1.2 percentage points in 1991 and 1992, and 2.0 percentage points, in 1999, outrunning the monthly average inflation rate in six out of 11 years during the period 1991-2001. The highest value of monthly average change of prices for services was $11.8 \%$ (1993), and the lowest $2.6 \%$ (2001).

Table 1 Evolution trends of monthly average inflation rate and monthly average change of prices during the period 1991-2001

\begin{tabular}{|c|c|c|c|c|c|c|}
\hline & \multirow{2}{*}{$\begin{array}{l}\text { Multiple } \\
\text { R }\end{array}$} & \multirow{2}{*}{$\begin{array}{l}\text { Standard } \\
\text { error }\end{array}$} & \multirow{2}{*}{$\begin{array}{c}\text { Significance } \\
\text { F }\end{array}$} & \multicolumn{3}{|c|}{ Regression Coefficient } \\
\hline & & & & $\mathrm{b}$ & Lower & Upper \\
\hline Rate of inflation & 0.73418 & 2.61576 & 0.01009 & -0.80909 & -1.37328 & -0.24490 \\
\hline Food goods & 0.77321 & 2.69776 & 0.00525 & -0.94091 & -1.52278 & -0.35903 \\
\hline Non-food goods & 0.68583 & 2.76212 & 0.01982 & -0.74454 & -1.34030 & -0.14878 \\
\hline Services & 0.62761 & 2.65723 & 0.03871 & -0.61273 & -1.18586 & -0.03959 \\
\hline
\end{tabular}

Source: authors own selection and interpretation of the data

During the period 1991-2001, the monthly average inflation rate and monthly average change of prices have had decreasing trends (Table 1). For the chosen significance level $(\alpha=0.05)$ the regression indices are statistically significant. As a result, the monthly average inflation rate registered a yearly average decrease of 0.80909 percentage points, the trust interval being [-1.37328, -0.2449]. As far as the monthly average change of prices is concerned, the most important decrease was by food goods $(-0.94091$ percentage points and trust interval $[-1.52278,-0.35903])$, followed by nonfood goods $(-0.74454$ percentage points and trust interval $[-1.3403,-0.14878])$ and services $(-0.61273$ percentage points and trust interval $[-1.18586,-0.03959])$.

\section{Methodology}

In order to analyze the monthly average inflation rate and monthly average change of prices, for food goods, non-food goods and for services, during the period 19912001, there were used least square methods, the validation of the obtained regression models being performed by means of the ANOVA methodology. In the same time, testing 
the normality of the distribution of residuals was accomplished by using the JB test (Jarque and Bera, 1987). Based on the obtained results there were tested and analyzed the specific features of the indices evolution during Romania transition period to the market economy and, in the same time, the influence of the economic crisis on these price indices. The second part of the paper aims to present an analysis of the monthly evolution of consumer price indices for food products realized by means of the autoregressive AR(p) and mobile mean MA(q). Such as (Eckard,, 2003; Vogt and Johnson, (2011), Ostertagová and Ostertag, (2013):

$$
y_{t}=\phi_{0}+\sum_{i=1}^{p} \phi_{i} y_{t-i}+\varepsilon_{t}+\sum_{i=1}^{q} \theta_{i} \varepsilon_{t-i}
$$

Where $\phi_{i}$ şi $\theta_{i}$ are the parameters of the model and $M\left(\varepsilon_{t}\right)=0$ the stationary series,

$$
M\left(\varepsilon_{t}\right)=0, M\left(\varepsilon_{t}^{2}\right)=\sigma^{2} \text { and } \operatorname{cov}\left(\varepsilon_{t}, \varepsilon_{i}\right)=0 \forall t \neq i
$$

In order to test the stationary of the monthly series evolution of consumer price indices for food products there was used Augmented Dickey-Fuller Test, and for the seasonal adjustment there was made use of the Multiplicative Method. After checking the stationarity and eliminating the seasonal component, there were identified the values of the parameters of the model (1) with least square method. In order to test the validity of the obtained model we used the F statistics:

$$
F=\frac{R^{2}}{1-R^{2}} \cdot \frac{n-k-1}{k}
$$

where $k=p+q$. If $F>F_{\alpha ; k ; n-k-1}$ (respectively Prob (F-statistics) $\left.<\alpha\right)$;

The model is considered valid and can be used in the forecast of monthly evolution of consumer price indices for food products. The level of significance which has been used is $\alpha=0.05$.

\section{Evolutions of the monthly average of prices change}

\section{Specific Features of the period 2001-2015}

After the 2001, both monthly average inflation rate, and monthly average change of prices have registered increasingly low values which, starting with 2004, have been lower than $1.0 \%$. (Figure 2). 


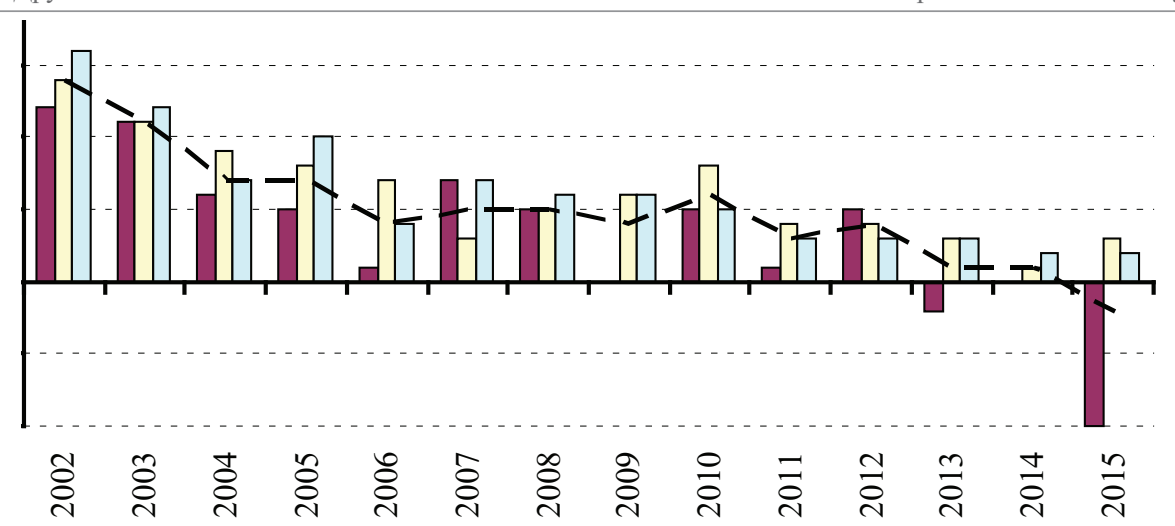

$\square$ Food goods $\square$ Non-food goods $\square$ Services - Rate of inflation

Note: For 2015, the values were calculated as June / July - 2015

Figure 2. Evolution of monthly average inflation rate and monthly average change of prices during the period 2002-2015. Source: own construction based on Prices Statistical Bulletin, National Institute of Statistics (NIS 2015), Data series Change of prices - monthly average

These evolutions emphasize the equilibrium tendency of the Romanian economy. It is worth mentioning that the economic crisis, debuting in the end of 2008, has not significantly influenced monthly average inflation rate or monthly average change of prices for food products, non-food products and services. Analyzing the evolutions of monthly average change of prices by comparison to monthly average inflation rate, it is worth emphasizing that, with the exception of 2007 and 2012, monthly average change of prices for food products, have been lower or, at its best, equal to monthly average inflation rate with values comprising 0 (in 2003 and 2008) and - 0.8 percentage points (in July 2015 compared to June 2015). Concerning the monthly average change of prices for non-food product and for services, excepting 2007, for non-food products and 2010 and 2012 , for services, these have had values higher or equal to monthly average inflation rate between 0 and 0.5 percentage points for non-food products, respectively between 0 and 0.4 percentage points for services.

Table 2 Evolution Trends of monthly average inflation rate and monthly average change of prices during the period 2002-2015

\begin{tabular}{|l|c|c|c|c|c|c|}
\hline & \multirow{2}{*}{$\begin{array}{c}\text { Multiple } \\
\mathrm{R}\end{array}$} & \multirow{2}{*}{$\begin{array}{c}\text { Standard } \\
\text { error }\end{array}$} & \multirow{2}{*}{$\begin{array}{c}\text { Significance } \\
\mathrm{F}\end{array}$} & \multicolumn{3}{|c|}{ Regression Coefficient } \\
\cline { 5 - 7 } & & & $\mathrm{b}$ & Lower & Upper \\
\hline Rate of inflation & 0.89736 & 0.18635 & 0.00001 & -0.08703 & -0.11395 & -0.06011 \\
\hline Food goods & 0.80728 & 0.34279 & 0.00048 & -0.10769 & -0.15721 & -0.05817 \\
\hline Non-food goods & 0.85495 & 0.19392 & 0.00009 & -0.07341 & -0.04539 & -0.10142 \\
\hline Services & 0.67171 & 0.20873 & 0.00004 & -0.08527 & -0.11543 & -0.05512 \\
\hline
\end{tabular}

Source: authors own selection and data interpretation

The decreasing trends registered during the period 1991-2001 remained the same during the period 2002-2015 for all analyzed indices (Table 2). Taking into account that 
Significance $F$ is much lower than the chosen significance level $(\alpha=0.05)$, results that all the regression indices were statistically significant. During the period 2002-2015 monthly average inflation rate had a yearly average decrease of 0.080703 percentage points, the trust interval being [-0.11395, -0.06011]. Monthly average change of prices for food goods was -0.10769 percentage points (trust interval $[-15721,-0.05817]$ ), followed by services $(-0.08527$ percentage points and trust interval $[-0.11543,-0.05512])$ and non-food goods $(-0.07341$ percentage points and trust interval $[-0.04539,-0.10142])$.

\section{Are there significant differences between the data series?}

In order to test the hypothesis regarding the existence of significant differences between the data series of the monthly average change of prices for food products, nonfood products and services there was used the ANOVA methodology, the results being presented in the table 3 .

Table 3 The results of testing the hypothesis regarding the existence of significant differences between the data series of monthly average change of prices for food products, non-food products and services

\begin{tabular}{|c|l|c|r|c|c|c|c|c|}
\hline Period & Source of Variation & \multicolumn{1}{c}{$S S$} & $d f$ & $M S$ & $F$ & P-value & F crit & Acc. \\
\hline \multirow{2}{*}{$1991-2001$} & Between Groups & 1.2897 & 2 & 0.6448 & 0.0486 & 0.9525 & 3.3158 & \multirow{2}{*}{$\mathrm{H}_{0}$} \\
\cline { 2 - 9 } & Within Groups & 397.37 & 30 & 13.246 & & & & \\
\hline \multirow{2}{*}{$2002-2015$} & Between Groups & 0.7619 & 2 & 0.3809 & 1.8799 & 0.1661 & 3.2380 & \multirow{2}{*}{$\mathrm{H}_{0}$} \\
\cline { 2 - 7 } & Within Groups & 7.9028 & 39 & 0.2027 & & & & \\
\hline
\end{tabular}

Source: authors own selection and data interpretation

Taking into account that for the three categories of products, both during the period 1991-2001 and during the period 2002-2015, the statistics F (0.0486 for the first period and 1.1661 for the second period) is lower than critical F (3.3158 and respectively 3.2380) and it is accepted the null hypothesis and, as a consequence, the corresponding data series monthly average change of prices for food products, non-food products and services is not significantly different.

\section{Time series analysis of monthly consumer price indices for food products}

The monthly evolution of consumer price indices for food products in the years 1991 - 2015 had an evolution similar to monthly average inflation rate analyzed above. The first decade of the analyzed period has been characterized by fluctuations of the consumer price indices for food products around a decreasing trend (Figure 3) which has continued during the next decades, though with a much lower slope. 


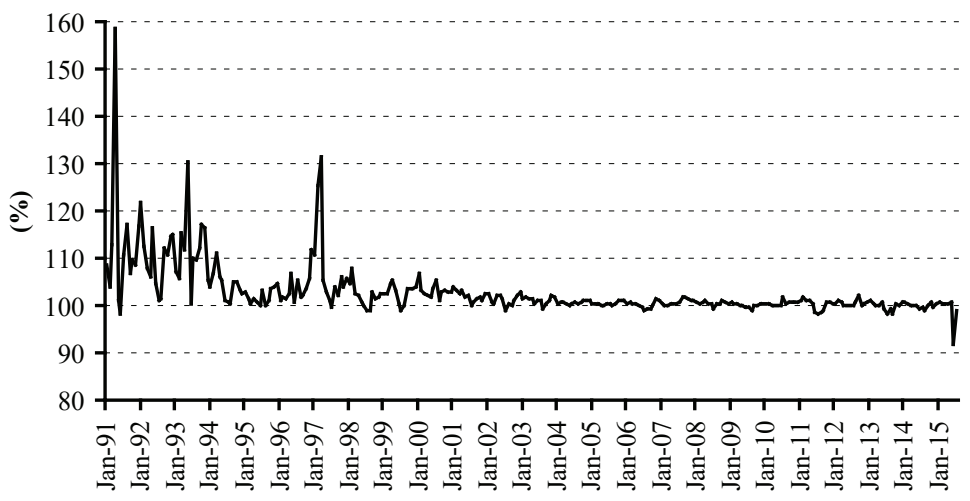

Figure 3. Evolution of monthly evolution of consumer price indices for food products in the years 1991 - 2015. Source: own construction based on Prices Statistical Bulletin,

National Institute of Statistics (NIS 2015), Data series Consumer Price Indices Monthly evolution in the years 1990 - 2015

Starting from these observations, this chapter emphasizes some specific features of the consumer price indices for food products as a time series with the emphasizing of the seasonal component, of the trend and of the autoregressive model which characterizes the evolution of consumer price indices for food products for the last 25 years.

In order to identify the seasonal factors there were used both Moving Average Method (Multiplicative adjustment method) and X12 method (multiplicative method). The seasonal factors which characterize the monthly evolutions of the consumer price indices for food products are presented in figure 4 . The values of ratio to moving average take values between a maximum of 1.01064, corresponding to March, and a minimum of corresponding to June. Ratio Evolutions to moving average during the period 1991-2015 emphasize that, for food products, starting with September, until December, in Romania, there takes place a relatively constant growth of the prices for food products. The growth of the prices for food products has been maintained during the first semester of the next year and reaches the maximum of their values.

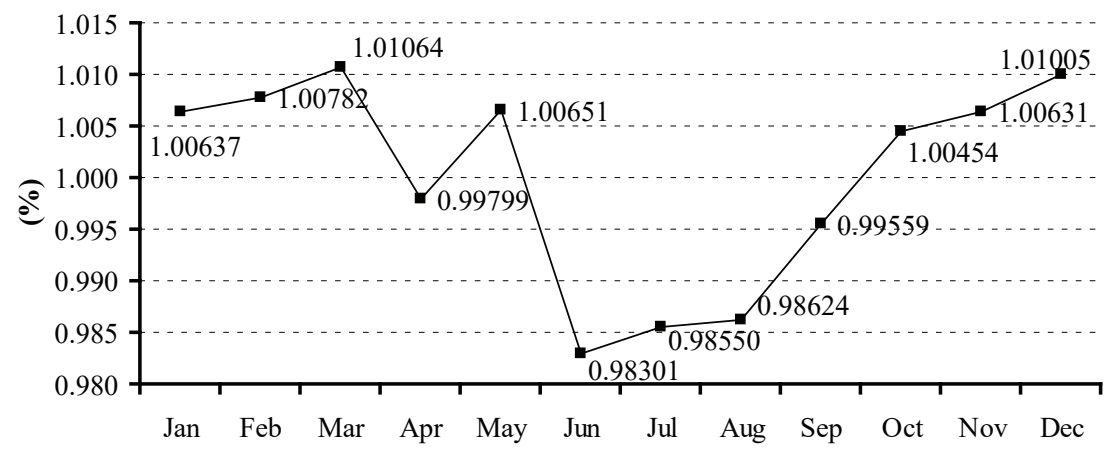

Figure 4 Ratio to moving average for monthly consumer price indices for food products. Sample: 1991:01 2015:07, Included observations: 295 (Multiplicative adjustment method). Source: authors own design 
During April and May the seasonal factors are approximately equal to 1, the influence of the seasonality on the monthly consumer price indices for food products is insignificant. In June, July and august, from the consumer point of view the seasonal factors have a favorable influence, these factors leading to the lowest prices of the food products within the entire year. Taking into account the evolution of the monthly consumer price indices for food products and applying Census X12 method (multiplicative method) there were obtained four data series: final seasonal factors, final seasonally adjusted series, final irregular component and final trend-cycle. Data series of the final seasonal factors for monthly consumer price indices for food products (CPIFP_SF) contains the evolution of the seasonality factors for each year of the analyzed period. The CPIFP_SF evolution is presented in figure 5 .

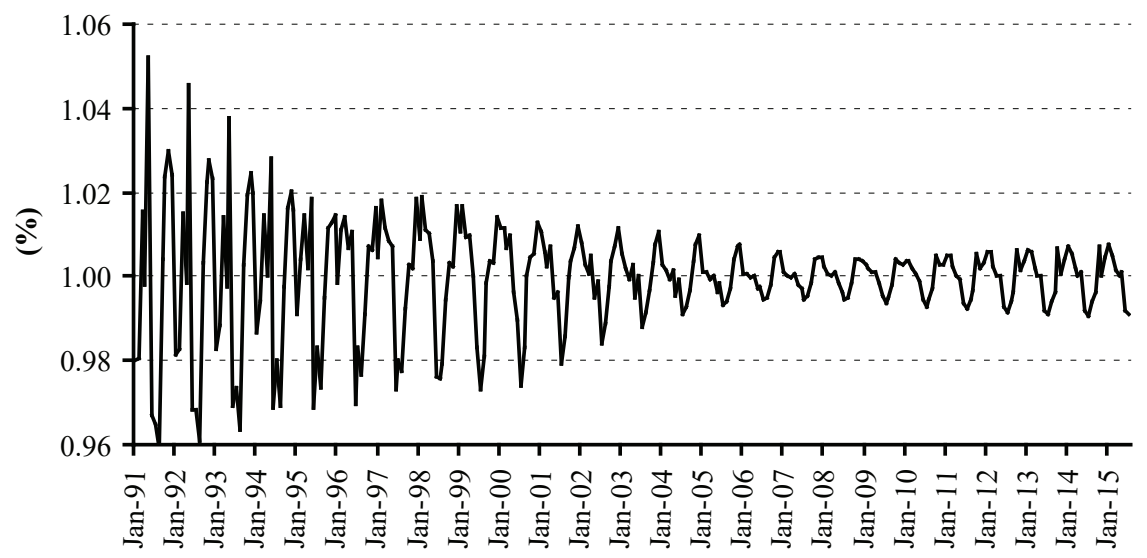

Figure 5. Final seasonal factors for monthly consumer price indices for food products (CPIFP_SF) in the period 1991-2015. Source: authors own design

During 1991 - 2003 took place a significant decrease of the seasonality influence on the price for the food products. This decrease, though much slowly, has continued until 2009.

After 2009 the seasonality influence on the prices for food products has become slightly divergent.. This aspect emphasizes the existence of a slight seasonal instability of the price for food products which, if it continues, it will have negative influences on the markets for food products.

The trend of monthly consumer price indices for food products (CPIFP TC) it is computed through the adjusting process of the monthly consumer price indices for food products (CPIFP) cu series CPIFP_SF and final irregular component of monthly consumer price indices for food products (CPIFP_IR) for every moment of the time:

$$
C P I F P_{-} \mathrm{TC}(t)=\frac{C P I F P(t)}{C P I F P_{-} \mathrm{SF}(t) \cdot C P I F P_{-} R(t)}
$$

The evolution of CPIFP_TC series (Figure 6) also emphasizes significant differences for the trend of the monthly consumer price indices for food products during the period 2002-2015 compared to the period 1991-2001. 


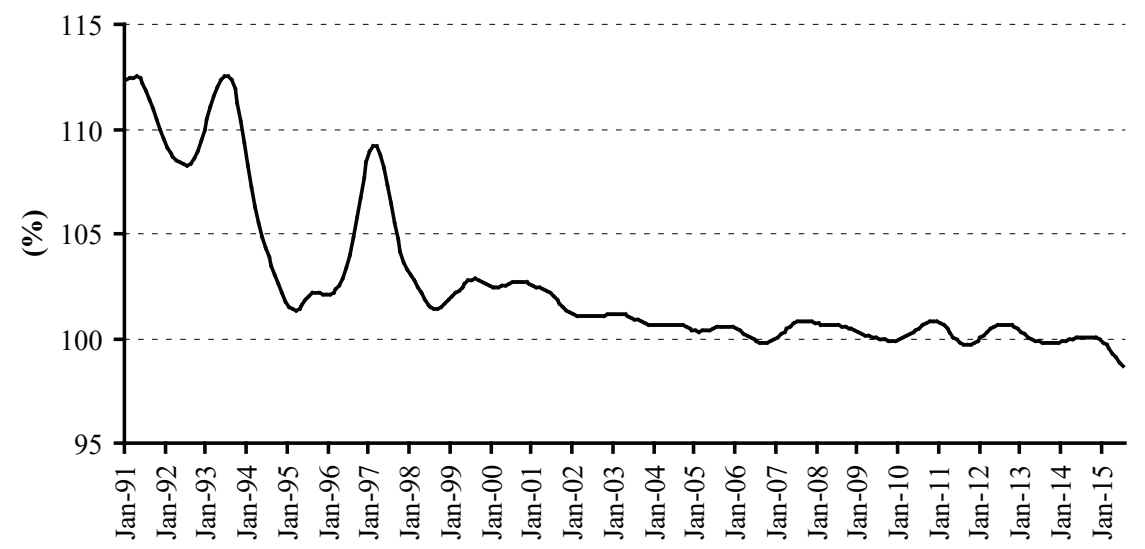

Figure 6 Final trend cycle for monthly consumer price indices for food products

(CPIFP_TC) in the period 1991-2015. Source: authors own design

Taking into account that the evolution of the monthly consumer price indices for food products during the period 1991-2001 was influenced in the first place by the processes and phenomena of Romania transition period to the market economy, there was extracted from the CPIFP_TC series the CPIFPR subseries corresponding to the period January 2002 -June 2015.

The results of testing the stationarity of the CPIFRP series and of its first difference, DCIPFPR, are presented in Table 4. Both CPIFPR series and DCIPFPR serie are stationary, fact outlined by the results obtained by means of applying Augmented Dickey-Fuller Unit Root Test (for the chosen significance level $\alpha=0.05$, t-Statistc $<-2.880853$ and, as a consequence, the null hypothesis is rejected).

Table 4 The results of Augmented Dickey-Fuller Unit Root Test for CPIFPR and DCPIFPR series

\begin{tabular}{|c|c|c|c|c|c|}
\hline & \multirow{2}{*}{ Null Hypothesis: } & \multicolumn{2}{|c|}{ CPIFPR has a unit root } & \multicolumn{2}{|c|}{ DCPIFPR has a unit root } \\
\hline & & $\mathrm{t}$-Statistic & Prob.* & $\mathrm{t}$-Statistic & Prob.* \\
\hline Augmented Dickey & Fuller test statistic & -4.087851 & 0.0013 & -3.267806 & 0.0086 \\
\hline Test critical values: & $\begin{array}{l}1 \% \text { level } \\
5 \% \text { level }\end{array}$ & $\begin{array}{l}-3.474567 \\
-2.880853\end{array}$ & & & \\
\hline
\end{tabular}

Source: authors own calculus

Monthly consumer price indices for food products during January 2002 - June 2015 after testing the series CPIFPR and DCPIFPR, choose the series CPIFPR. Therefore the model of development will be ARMA (n, m). Among the performing models tested the best was obtained for ARMA model (4.3) as:

$$
\mathrm{CPIFPR}=100.2488+[\mathrm{AR}(4)=0.850324, \mathrm{MA}(3)=0.992554, \mathrm{INITMA}=2002: 05]
$$


Of which characteristics are presented in table 5.

Table 5 testing of the parameters of $\operatorname{ARMA}(4,3)$ model for the CPIFPR series

\begin{tabular}{crcrr}
\hline Variable & Coefficient & Std. Error & t-Statistic & Prob. \\
\hline \hline C & 100.2488 & 0.178928 & 560.2746 & 0.0000 \\
AR(4) & 0.850324 & 0.042436 & 20.03780 & 0.0000 \\
MA(3) & 0.992554 & 0.018224 & 54.46407 & 0.0000 \\
\hline R-squared & 0.853861 & F-statistic & & 452.8170 \\
Adjusted & 0.851975 & Prob(F-statistic) & 0.000000 \\
R-squared &
\end{tabular}

Dependent Variable: CPIFPR, Method: Least Square, Included observations: 158 after adjusting endpoints, Convergence achieved after 5 iterations

Source: own determination

Both model (2) and all its three parameters are statistically significant (F-statistic $=0.00$, respective Prob $=0.00<\alpha=0.05$ ). Regarding the residuals series for sample 2002:05 - 2015:06, this has a normal distribution with Mean=-0.0114, Skewness $=-0.1445$, Kurtosis $=3.333$ and for which $\mathrm{JB}=1.2797$ (Probability $=0.5274$ ).

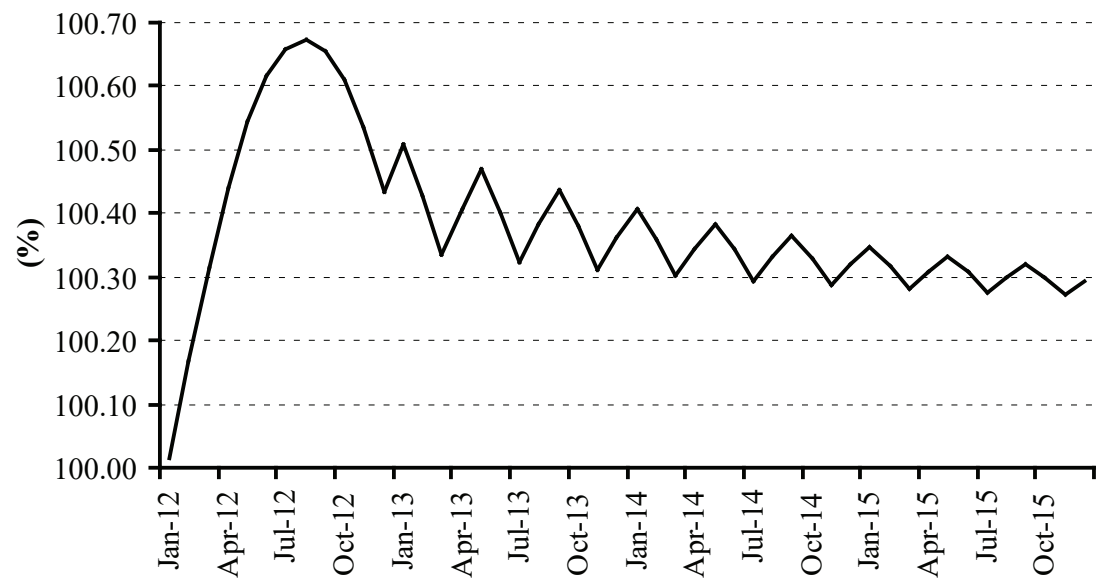

Figure 7 Estimation of the monthly consumer price indices for food products evolution

(CPIFPR_D) in the period Jan-2012 - Dec-2015. Source: authors own design

Starting from the model (2) it was estimated the evolution of the monthly consumer price indices for food products during the period January 2012 -December 2015 (Figure 7). This represents tending to the equilibrium value of $100.3 \%$. As a result, if there are not registered significant changes within the social media and the economic monthly consumer rate indices for food products will be of approximately $0.3 \%$.

\section{Conclusion}

The paper had as main research theme the analysis of evolution of the consumer price indices in Romania, during 1991-2015 in terms of inflation stability in a country that 
has experienced the transition to a functional and highly economy competitive market. Price index fluctuations represent a fundamental element in understanding the mechanism of functioning of the Romanian inland economy. Econometric analysis conducted in this paper highlighted the specific features of an economy at the confluence of the requirements of the market economy to those of an indirect intervention of the state in the global economy. Reducing inflation due to decreased VAT rate linked a significant reduction in the level of consumer prices and thus inflation. Volatility of the consumer price indices in Romania is by itself an important problem that requires a coherent management solution multivalent in terms of price policy. As results from the analysis performed, evolution of the consumer price indices in Romania is syncope with different amplitude that can be like a general framework in highlighting the national economy behavior.

\section{References}

Andrei, T., Stancu, S., Iacob A.I., Tuşa, E. (2008). Introducere în econometrie utilizând EViews, Editura Economică, Bucharest. Romania (In Romanian)

Assenmacher-Wesche, K., Gerlach, S.( 2008). Interpreting euro area inflation at high and low frequencies. European Economic Review, (52):964-986.

Breitung, J., Candelon, B.( 2006). Testing for short and long-run causality: a frequency domain approach. Journal of Econometrics, (132): 363-378

Caporale, G.M., Katsimi, M., Pittis, N.( 2002). Causality links between consumer and producer prices: some empirical evidences. Southern Economic Journal,(68): 703-711.

Chivu, L., Ciutacu, C. (2014).About industrial structures decomposition and decomposition. Procedia Economics and Finance, (8):157-166.

Eckard, E. W. (2003). The ANOVA-based competitive balance measure: a defense. Journal of Sports Economics, 4(1):74-80.

Gros, D., Steinherr, A. (2004). Economic transition in Central and Eastern Europe: Planting the seeds. Cambridge University Press.

Jarque, C.M., Bera, A.K.(1987). A test for normality of observations and regression residuals. International Statistical Review, 55 (2), 163-172.

Kilian, L., Lewis, L.T., 2011. Does the fed respond to oil price shocks? Econ. J. 121, 1047-1072.

Liping, G., Hyeongwoo, K., Saba, R.(2014). How do oil price shocks affect consumer prices?, Energy Economics (45):313-323.

Mieila, M. (2012). Selection of Investment Projects in Situations of Discordance between Criteria of Efficiency Assessment. Valahian Journal of Economic Studies, 3(4), 57.

Montgomery, D.C. (2001). Design and Analysis of Experiments (5th ed.). New York: Wiley.

Moore, David S., McCabe, George P. (2003). Introduction to the Practice of Statistics (4e). W H Freeman \& Co. 
Oprea, C., Zaharia, M. (2011). Elemente de analiza datelor şi modelare utilizând Excel (Elements of data analysis and modeling using Excel), Editura Universitară, Bucharest, Romania (In Romanian).

Ostertagová, E., Ostertag, O.(2013).Methodology and Application of Oneway ANOVA. American Journal of Mechanical Engineering, 1(7):256-261.

Parguel, B., Delécolle, T., Valette-Florence, P. (2016). How price display influences consumer luxury perceptions, Journal of Business Research, (69):341-348.

Pecican E.Ş. (2007). Econometria pentru... economişti (3ed.). Editura Economică, Bucharest, Romania (In Romanian).

Săvoiu Gh. \& Necşulescu C. (2009). Econometrie, Editura Universitară (http://www. editurauniversitara.ro), Bucharest, Romania (In Romanian).

Skoufias, E. (2003). The structure of wages during the economic transition in Romania. Economic systems, 27(4):345-366.

Svejnar, J. (2002). Transition economies: Performance and challenges. The Journal of Economic Perspectives, 16(1), 3-28.

Trancea I.I., Mutu S.S. (2012). Managementul riscurilor bancare - Soluţii economice. Editura Cărţii de Ştiinţă, Cluj-Napoca, Romania (In Romanian).

Truong, Y., McColl, R., Kitchen, P. J. (2009). New luxury brand positioning and the emergence of masstige brands. Journal of Brand Management, 16(5):375-382.

Verhallen, T. M., Robben, H. S. (1994). Scarcity and preference: An experiment on unavailability and product evaluation. Journal of Economic Psychology, 15(2), $315-331$.

Verhallen, T. M., Robben, H. S. (1994). Scarcity and preference: An experiment on unavailability and product evaluation. Journal of Economic Psychology, 15(2):315-331.

Vogt, W. P., Johnson, R. B. (2011). Dictionary of Statistics \& Methodology: A Nontechnical Guide for the Social Sciences: A Nontechnical Guide for the Social Sciences. Sage.

Zaharia M., Bălăcescu A. (2011). Modelarea deciziei monetar financiare. Editura Universitaria Craiova, Romania (In Romanian).

NIS(2015).Prices Statistical Buletin 7/2015, Romanian National Institute of Statistics, Bucharest.

BNR (2015). Raport asupra inflatiei, noiembrie 2015, Romanian National Bank Bucharest. 